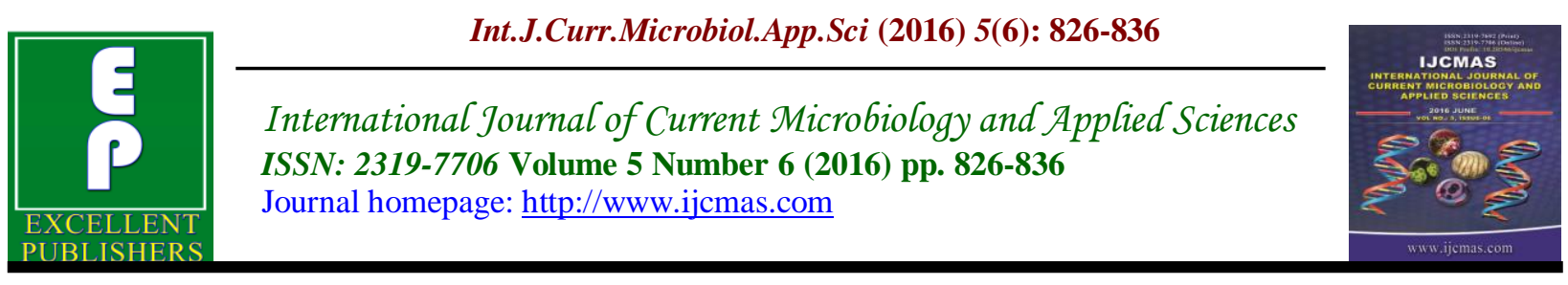

Original Research Article

http://dx.doi.org/10.20546/ijcmas.2016.506.091

\title{
Productivity and Nutrient Uptake of Rice Fallow Maize (Zea mays L.) as Influenced by Plant Density and Fertilizer N Under No-Till Conditions
}

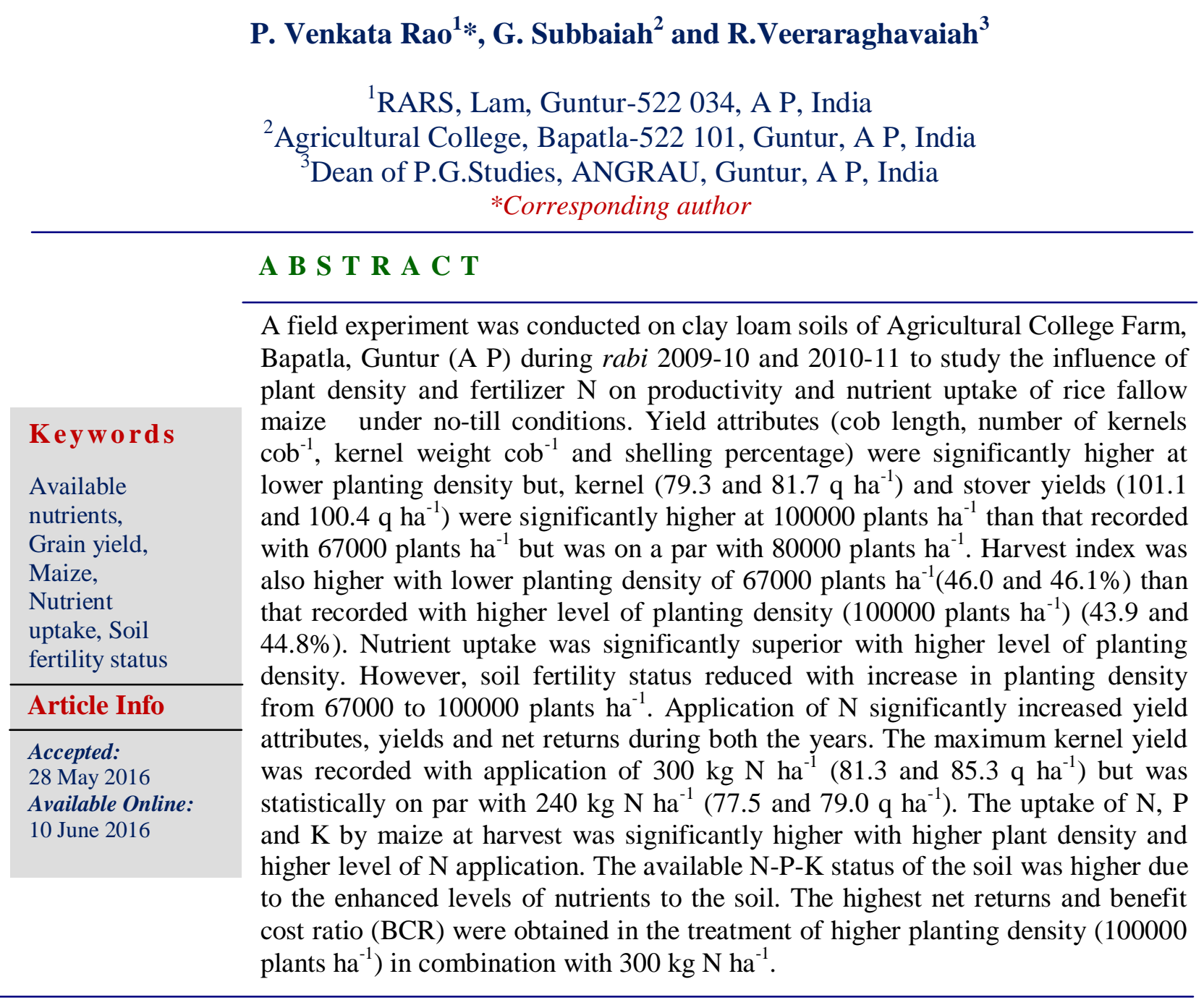

\section{Introduction}

Maize (Zea mays L) is one of the most versatile emerging crops having wider adaptability under varied agro-climatic conditions and successful cultivation in diverse seasons and ecologies for various purposes. Globally, maize is known as "Queen" of cereals because it's highest genetic yield potential among cereals. It is cultivated on nearly $150 \mathrm{~m}$ ha in about 160 countries having wider diversity of soil, climate, biodiversity and management practices that contributes 36 per cent $(782 \mathrm{~m}$ t) in the global grain production. Currently, it is cultivated in India in an area of $9.4 \mathrm{~m}$ ha 
with a production of $23.0 \mathrm{~m} \mathrm{t}$ and productivity of $2447 \mathrm{~kg} \mathrm{ha}^{-1}$. In Andhra Pradesh, it is grown in an area of 3.52 lakh ha with a production of $2.21 \mathrm{~m} \mathrm{t}$ (Anon. 2015). In addition to staple food for human being and quality feed for animals, maize serves as a basic raw material as an ingredient to thousands of industrial products that include starch, oil, protein, alcoholic beverages, food sweeteners, pharmaceutical, cosmetic, film, textile, gum, package and paper industries etc.

In recent years, rice - maize sequence is gaining popular in place of rice - blackgram in the Krishna and Godavari agro-climatic zones of Andhra Pradesh due to late release of canal water, severe weed and disease problems, poor yields of pulses and less remunerative prices. Rice fallow maize under no-till is practiced by farmers for multipurpose viz; grain, dairy, poultry and vegetable. Farmers accepted rice-maize as a beneficial cropping system and growers adopted this system to increase their efficiency and profitability and to improve their environmental stewardship. Potentiality of maize crop for its growth and development can be fully exploited by adopting suitable agronomic practices such as optimum spacing, fertilizers especially $\mathrm{N}$. The beneficial effects of nitrogen on crop production are well documented however, nitrogen mining by crops for optimum productivity widely vary on account of different agro-climates, soils, cultivars, management practices and other factors. The farmers of this region are using huge quantities of inorganic commercial fertilizers untimely and indiscriminately to get better yields in maize under rice fallow situations. Continuous use of inorganic sources of $\mathrm{N}$ leads to decline or stagnation in productivity due to limitation of one or more nutrients. Indiscriminate use of chemical fertilizers and agro-chemicals rendered the arable soils unproductive as a consequence of unfavourable physical, chemical and biological characteristics of soil. The production technology for no-till maize in respect of plant density and nitrogen management is not available. In order to avoid the excess use of nitrogenous fertilizers and to maintain the sustainable productivity of the system, the present investigation was undertaken to study the productivity and nutrient uptake of rice fallow maize (Zea mays L. ) as influenced by plant density and nitrogen management under no-till conditions.

\section{Materials and Methods}

A field experiment was conducted for two consecutive years (2009-2010 and 20102011) at Agricultural College Farm, Bapatla, Guntur (A P) on sandy clay loam soil with a pH 8.0, OC 0.3\%, available N (192 $\left.\mathrm{kg} \mathrm{ha}^{-1}\right)$, available $\mathrm{P}_{2} \mathrm{O}_{5}\left(37 \mathrm{~kg} \mathrm{ha}^{-1}\right)$ and available $\mathrm{K}_{2} \mathrm{O}\left(740 \mathrm{~kg} \mathrm{ha}^{-1}\right)$. The experiment was laid in split-plot design and the treatments were replicated thrice. There are 12 treatment combinations in the study which comprised of three planting densities (D) viz., $\mathrm{D}_{1}$ : $67000(60 \mathrm{~cm} \times 25 \mathrm{~cm})$ plants $\mathrm{ha}^{-1} ; \mathrm{D}_{2}$ : $80000(50 \mathrm{~cm} \times 25 \mathrm{~cm})$ plants $\mathrm{ha}^{-1}$ and $\mathrm{D}_{3}$ : $100000(40 \mathrm{~cm} \times 25 \mathrm{~cm})$ plants $\mathrm{ha}^{-1}$ allotted to main plots and four nitrogen levels $(\mathrm{N})$ viz. $\mathrm{N}_{1}: 120 ; \mathrm{N}_{2}: 180: \mathrm{N}_{3}: 240 \& \mathrm{~N}_{4}: 300 \mathrm{~kg}$ $\left.\mathrm{ha}^{-1}\right)$ as sub plot treatments. The fertilizers of $\mathrm{P}\left(60 \mathrm{~kg} \mathrm{P}_{2} \mathrm{O}_{5} \mathrm{ha}^{-1}\right)$ and $\mathrm{K}\left(40 \mathrm{~kg} \mathrm{~K}_{2} \mathrm{O} \mathrm{ha}{ }^{-1}\right)$ were applied through Single superphosphate (SSP) and Muriate of potash (MOP) as basal at the time of sowing uniformly to all the treatments. Maize hybrid "Pioneer 30V 92" was sown on 04-01-2010 and 08-1-2011 under zero tillage conditions and harvested on 19-4-2010 and 23-4-2011during first and second year respectively. A total of 14.1 and $137.5 \mathrm{~mm}$ rainfall was received during the study period of both the years. 
Maize was sown under zero tillage conditions immediately after harvest of kharif rice by dibbling two seeds per hill with the help of pointed bamboo peg and marked nylon ropes as per the treatments. Thinning and gap filling was done with utmost care at 10 DAS by keeping one seedling hill ${ }^{-1}$. Required quantity of $\mathrm{P}$ and $\mathrm{K}$ was applied through Single super phosphate (SSP) $\left(16 \% \mathrm{P}_{2} \mathrm{O}_{5}\right)$ and Muriate of potash (MOP) $\left(60 \% \mathrm{~K}_{2} \mathrm{O}\right)$, respectively to all the treatments as basal. Nitrogen was applied in three splits i.e. at basal, 25 and 55 DAS as as per the treatments in the form of Urea $(46 \% \mathrm{~N})$. The crop was maintained by adopting the recommended package of practices. A total of three light irrigations were given immediately after application of fertilizers. Pre-emergence application of weedicides viz., Paraquat @ $10 \mathrm{ml} \mathrm{l}^{-1}$ and Atrazine @5 $\mathrm{g} \mathrm{l}^{-1}$ were applied on second day after sowing of maize for prevention of re-growth of paddy stubbles and to control the germinating weeds. Need based plant protection measures were taken up during crop growth period. The data on plant height, dry matter accumulation, yield attributes and yield were recorded in both the years and analysed as per standard statistical procedures.

\section{Results and Discussion}

\section{Yield Attributes and Yield}

Plant population had significant influence on all yield attributes and yield. Kernel and stover yields were significantly influenced by planting densities and levels of $\mathrm{N}$ given to maize. Irrespective of $\mathrm{N}$ levels given to maize, yield attributes (cob length, number of kernels $\mathrm{cob}^{-1}$, kernel weight $\mathrm{cob}^{-1}$, shelling percentage and test weight), were reduced with increase in planting densities from 67000 to 100000 plants ha- ${ }^{-1}$ (Table 1). The longest cob (19.2 cm and $20.2 \mathrm{~cm}$, respectively, in both the years), the highest number of kernels $\operatorname{cob}^{-1}$ (559 and 579), kernel weight $\operatorname{cob}^{-1}(185$ and 216), shelling percentage (77.6 and 75.1) and test weight $(29.5 \mathrm{~g}$ and $31.4 \mathrm{~g})$ were recorded with planting density $\left(\mathrm{D}_{1}: 67000\right.$ plants $\left.^{-1}\right)$. The highest kernel yield of 78.7 and $81.7 \mathrm{q} \mathrm{ha}^{-1}$ (2009-10 and 2010-11) was with higher planting density of 100000 plants ha ${ }^{-1}$ during first and second year, respectively, however, it did not reach the level of significance with 80000 plants ha ${ }^{-1}\left(73.0\right.$ and $\left.76.8 \mathrm{q} \mathrm{ha}^{-1}\right)$. Significantly higher kernel and stover yields recorded with higher planting density might be due to higher number of plants per unit area compensated for lower yields plant $^{-1}$ resulting in higher kernel yield at higher plant populations. Vishalu et al. (2009) and Venkata Rao et al. (2014) also reported similar trend of increase in kernel yield with increase in plant density. Reduction in cob length and shelling percentage might be attributed to reduced supply of photosynthates to the sink. These results are supported by Barbieri et al. (2008) and Emam (2001) who observed that kernels $\mathrm{cob}^{-1}$ and kernels weight $\mathrm{cob}^{-1}$ are the most important yield adjustment components in response to plant population density in maize. Similar reduction in test weight (100 grain) at higher plant density might be due to decrease in leaf area plant ${ }^{-1}$ with increase in plant population and consequent reduction in photosynthates during reproductive phase. The present findings are in consonance with Reddy et al. (2012) and Van Roekel and Coulter (2011).

Irrespective of planting densities, yield components (cob length, kernel weight $\mathrm{cob}^{-}$ 1 , number of kernels $\mathrm{cob}^{-1}$, shelling percentage and test weight) and yield increased with increase in level of $\mathrm{N}$ application from 120 to $300 \mathrm{~kg} \mathrm{~N} \mathrm{ha}^{-1}$ (Table $1 \& 2$ ). The highest kernel yield of 81.3 and $85.3 \mathrm{q} \mathrm{ha}^{-1}$, respectively, was observed with $300 \mathrm{~kg} \mathrm{~N} \mathrm{ha}{ }^{-1}$ during both the years of investigation (Table 2) and was significantly 
superior to that of $120 \mathrm{~kg} \mathrm{~N}$ and $180 \mathrm{~kg} \mathrm{~N}$ but not with that of $240 \mathrm{~kg} \mathrm{~N} \mathrm{ha}{ }^{-1}$. Significant increase in yield-attributing characters, viz cob length, number of kernels $\mathrm{cob}^{-1}$, kernel weight $\mathrm{cob}^{-1}$ and test weight with the application of higher doses of nitrogen might be responsible for improvement in kernel yield. Adequate supply of $\mathrm{N}$ might have helped the maize plants to increase their growth which in turn put forth more photosynthetic surface and chlorophyll content, thus contributing for more dry matter accumulation.

Similar results were also reported earlier by Bharathi (2010) and Jantalia and Halvorson (2011). The positive response to higher level of nitrogen on kernel yield could be ascribed to overall improvement in growth which enabled the plant to absorb more quantity of photosynthates accumulating in sink. These results are in concordance with the findings of Lakshmi (2010) and Venkata Rao et al. (2014).

Harvest index and shelling percentage showed a similar trend as that of other yield attributes with the maximum and the most effective dose being $300 \mathrm{~kg} \mathrm{~N}^{-1}$ in first year but was statistically on a par with 240 $\mathrm{kg} \mathrm{N} \mathrm{ha}{ }^{-1}$ in second year. Shelling percentage was influenced significantly up to $300 \mathrm{~kg} \mathrm{~N} \mathrm{ha}^{-1}$ during both the years of study. Likewise, cob length was the maximum with $300 \mathrm{~kg} \mathrm{~N}^{-1}(19.1 \mathrm{~cm}$ and $20.1 \mathrm{~cm}$ in 2009-10 and 2010-11, respectively) which was statistically at par with $240 \mathrm{~kg} \mathrm{~N} \mathrm{ha}^{-1}(18.2 \mathrm{~cm}$ and $19.6 \mathrm{~cm}$, respectively). Higher levels of nitrogen produced cobs having better length which might be due to enhanced nitrogen supplements that led to an increase in leaf area, photosynthesis etc. which in turn resulted in the formation of healthy cobs. The present findings were in line with the findings of Ananthi et al. (2010), Reddy et al. (2012) and Venkata Rao et al.(2014).

\section{Nutrient Uptake}

Higher nutrient uptake (N, P and $\mathrm{K})$ by maize at maturity (kernel + stover) obtained at higher planting density (100000 plants ha $\left.{ }^{1}\right)$ compared to that of lower planting density (67000 plants ha ${ }^{-1}$ ) (Table 3). Higher uptake was primarily might be due to higher grain and stover yields. The overall increase in biomass with increased number of plants per unit area seems to have compensated negative effect of increased population on nutritional status in the plant parts. These findings were in close conformity with the results of Bisht et al. (2013).

Uptake of $\mathrm{N}, \mathrm{P}$ and $\mathrm{K}$ by maize crop increased significantly with the increase in $\mathrm{N}$ application from 120 to $300 \mathrm{~kg} \mathrm{ha}^{-1}$ (Table $3)$. The increased biomass production as well as concentration of $\mathrm{N}, \mathrm{P}$ and $\mathrm{K}$ in kernel and stover might also be the cause for higher uptake of N, P and K by the crop. Increased uptake of $\mathrm{N}, \mathrm{P}$ and $\mathrm{K}$ at higher levels of $\mathrm{N}$ might have resulted in initial build up of plants due to vigorous growth and high photosynthetic rate which led to better uptake throughout the crop growth period. When a considerable amount of $\mathrm{N}$ applied at or near anthesis, there is a greater possibility of its accumulation in sink rather than other vegetative parts. Similar, results on nutrient uptake was also reported by Bisht et al. (2013), Paramasivan et al. (2011) and Sutaliya and Singh (2005).

\section{Economics}

Gross returns, net returns and benefit cost ratio (BCR) worked out for rice fallow maize under zero tillage conditions by taking into consideration the inputs used and the crop produce (economic yield) for both the years of the investigation are presented in table 2. 
Table.1 Yield attributes of no-till maize under rice fallows as influenced by planting density and level of $\mathrm{N}$ application during rabi 2009-10 and 2010-11

\begin{tabular}{|c|c|c|c|c|c|c|c|c|c|c|}
\hline \multirow{2}{*}{$\begin{array}{c}\text { Treatments } \\
\text { Plant density (plants } \mathrm{ha}^{-1} \text { ) }\end{array}$} & \multicolumn{2}{|c|}{ Cob length (cm) } & \multicolumn{2}{|c|}{ No. of kernels $\operatorname{cob}^{-1}$} & \multicolumn{2}{|c|}{ Kernel weight $\operatorname{cob}^{-1}(\mathrm{~g})$} & \multicolumn{2}{|c|}{$\begin{array}{c}\text { Shelling } \\
\text { percentage }\end{array}$} & \multicolumn{2}{|c|}{ Test weight (g) } \\
\hline & 2009-10 & 2010-11 & 2009-10 & 2010-11 & 2009-10 & 2010-11 & $\begin{array}{c}2009- \\
10\end{array}$ & 2010-11 & 2009-10 & 2010-11 \\
\hline $\mathbf{D}_{1}-67000(60 \mathrm{~cm} \times 25 \mathrm{~cm})$ & 19.2 & 20.2 & 559 & 579 & 185 & 216 & 77.6 & 75.1 & 29.5 & 31.4 \\
\hline $\mathbf{D}_{2}-80000(50 \mathrm{~cm} \times 25 \mathrm{~cm})$ & 17.6 & 18.6 & 491 & 500 & 160 & 200 & 74.0 & 72.8 & 27.1 & 28.6 \\
\hline $\mathbf{D}_{\mathbf{3}}-100000(40 \mathrm{~cm} \times 25 \mathrm{~cm})$ & 16.1 & 17.6 & 435 & 438 & 141 & 188 & 70.4 & 70.8 & 25.1 & 27.0 \\
\hline $\mathrm{SEm} \pm$ & 0.3 & 0.3 & 18.7 & 13.4 & 4.1 & 3.9 & 0.7 & 0.4 & 0.4 & 0.4 \\
\hline $\mathrm{CD}(0.05)$ & 1.2 & 1.3 & 74 & 53 & 16 & 15 & 2.6 & 1.7 & 1.5 & 1.5 \\
\hline $\mathrm{CV}(\%)$ & 6.1 & 6.2 & 13.1 & 9.2 & 8.8 & 6.7 & 3.0 & 2.1 & 5.0 & 4.6 \\
\hline \multicolumn{11}{|l|}{ N levels $\left(\mathrm{kgha}^{-1}\right)$} \\
\hline $\mathbf{N}_{1-}-120$ & 15.8 & 17.1 & 418 & 413 & 128 & 178 & 70.8 & 70.8 & 25.4 & 27.1 \\
\hline $\mathbf{N}_{2}-180$ & 17.4 & 18.5 & 471 & 486 & 141 & 195 & 73.4 & 72.3 & 26.8 & 28.2 \\
\hline $\mathbf{N}_{3}-240$ & 18.2 & 19.6 & 521 & 531 & 153 & 208 & 74.6 & 73.3 & 27.8 & 29.3 \\
\hline $\mathbf{N}_{4-} 300$ & 19.1 & 20.1 & 570 & 592 & 168 & 224 & 77.2 & 75.3 & 28.9 & 31.5 \\
\hline $\mathrm{SEm}+$ & 0.6 & 0.4 & 10.0 & 15.4 & 5.1 & 4.4 & 0.7 & 0.7 & 0.7 & 0.9 \\
\hline $\mathrm{CD}(0.05)$ & 1.6 & 1.2 & 30.0 & 46 & 15 & 13 & 2.0 & 2.0 & 2.1 & 2.5 \\
\hline $\mathrm{CV}(\%)$ & 9.4 & 6.2 & 6.1 & 9.2 & 9.4 & 6.5 & 2.8 & 2.8 & 7.9 & 8.8 \\
\hline Interaction(PDXN) & NS & NS & NS & NS & NS & NS & NS & NS & NS & NS \\
\hline
\end{tabular}


Table.2 Yield and Economics of maize under rice fallows as influenced by planting density and N application

\begin{tabular}{|c|c|c|c|c|c|c|c|c|c|c|c|c|}
\hline \multirow{2}{*}{$\begin{array}{c}\text { Treatments } \\
\left.\text { Plant density (plants ha }{ }^{-1}\right)\end{array}$} & \multicolumn{2}{|c|}{ Kernel yield (q ha $\left.{ }^{-1}\right)$} & \multicolumn{2}{|c|}{ Stover yield $\left(\mathrm{q} \mathrm{ha}^{-1}\right)$} & \multicolumn{2}{|c|}{ HI (\%) } & \multicolumn{2}{|c|}{ Gross returns } & \multicolumn{2}{|c|}{ Net returns } & \multicolumn{2}{|c|}{ BCR } \\
\hline & 2009-10 & 2010-11 & 2009-10 & 2010-11 & 2009-10 & 2010-11 & 2009-10 & 2010-11 & 2009-10 & 2010-11 & 2009-10 & 2010-11 \\
\hline $\mathbf{D}_{1^{-}}-67000(60 \mathrm{~cm} \times 25 \mathrm{~cm})$ & 65.8 & 68.0 & 75.7 & 79.8 & 46.0 & 46.1 & 56893 & 71384 & 33827 & 48318 & 1.46 & 2.09 \\
\hline $\mathbf{D}_{2-} 80000(50 \mathrm{~cm} \times 25 \mathrm{~cm})$ & 73.0 & 76.8 & 92.9 & 92.5 & 44.3 & 45.4 & 63119 & 80664 & 38973 & 56518 & 1.61 & 2.33 \\
\hline $\mathbf{D}_{3}-100000(40 \mathrm{~cm} \times 25 \mathrm{~cm})$ & 78.7 & 81.7 & 101.2 & 100.4 & 43.9 & 44.8 & 68095 & 85769 & 43369 & 61043 & 1.75 & 2.46 \\
\hline $\mathrm{SEm} \pm$ & 1.8 & 1.7 & 2.5 & 2.7 & 0.4 & 0.3 & & & & & & \\
\hline $\mathrm{CD}(0.05)$ & 7.1 & 6.8 & 9.8 & 10.6 & 1.6 & NS & & & & & & \\
\hline $\mathrm{CV}(\%)$ & 8.6 & 7.9 & 9.6 & 10.3 & 3.1 & 2.3 & & & & & & \\
\hline \multicolumn{13}{|l|}{$\mathrm{N}$ levels $\left(\operatorname{kgha}^{-\mathbf{1}}\right)$} \\
\hline $\mathbf{N}_{\mathbf{1}^{-}} 120$ & 61.5 & 64.3 & 79.6 & 81.9 & 43.5 & 44.0 & 53186 & 67540 & 30407 & 44760 & 1.33 & 1.96 \\
\hline $\mathbf{N}_{2}-180$ & 69.6 & 73.4 & 88.0 & 89.7 & 44.0 & 45.1 & 60213 & 77042 & 36633 & 53463 & 1.55 & 2.26 \\
\hline $\mathbf{N}_{\mathbf{3}^{-}}-240$ & 77.5 & 79.0 & 93.9 & 93.6 & 45.0 & 45.9 & 76046 & 82971 & 42667 & 58592 & 1.75 & 2.40 \\
\hline $\mathbf{N}_{\mathbf{4}^{-}} 300$ & 81.3 & 85.3 & 98.2 & 98.4 & 46.4 & 46.7 & 70365 & 89537 & 45186 & 64358 & 1.79 & 2.55 \\
\hline $\mathrm{SEm} \pm$ & 2.4 & 2.4 & 3.1 & 3.8 & 0.4 & 0.6 & & & & & & \\
\hline $\mathrm{CD}(0.05)$ & 7.1 & 7.1 & 9.1 & 11.3 & 1.1 & 1.8 & & & & & & \\
\hline $\mathrm{CV}(\%)$ & 9.8 & 9.5 & 10.2 & 12.5 & 2.5 & 4.0 & & & & & & \\
\hline Interaction(PDXN) & NS & NS & NS & NS & NS & NS & & & & & & \\
\hline
\end{tabular}


Table.3 Nutrient uptake (kg ha-1) of maize under rice fallows as influenced by planting density and $\mathrm{N}$ application

\begin{tabular}{|c|c|c|c|c|c|c|c|c|c|c|}
\hline \multirow{2}{*}{ Treatments } & \multicolumn{3}{|c|}{ N uptake } & \multicolumn{3}{c|}{ P $_{\mathbf{5}}$ uptake } & \multicolumn{3}{c|}{ K$_{2}$ O uptake } \\
\cline { 2 - 11 } & Grain & Stover & Total $(\mathbf{A})$ & Grain & Stover & Total (B) & Grain & Stover & Total (C) & $($ A+B+C) \\
\hline $\mathrm{D}_{1} \mathrm{~N}_{1}$ & 73.1 & 27.5 & 100.6 & 18.8 & 9.3 & 28.1 & 16.2 & 83.2 & 99.4 & 228.1 \\
\hline $\mathrm{D}_{1} \mathrm{~N}_{2}$ & 83.9 & 31.4 & 115.3 & 21.3 & 10.8 & 32.1 & 19.3 & 97.8 & 117.1 & 264.5 \\
\hline $\mathrm{D}_{1} \mathrm{~N}_{3}$ & 93.1 & 35.8 & 128.9 & 24.8 & 12.3 & 37.1 & 22.6 & 109.5 & 132.1 & 298.1 \\
\hline $\mathrm{D}_{1} \mathrm{~N}_{4}$ & 103.6 & 43.9 & 147.5 & 27.9 & 13.4 & 41.3 & 25.4 & 121.7 & 147.1 & 335.9 \\
\hline $\mathrm{D}_{2} \mathrm{~N}_{1}$ & 86.1 & 37.5 & 123.6 & 22.6 & 11.4 & 34.0 & 21.2 & 98.4 & 119.6 & 277.4 \\
\hline $\mathrm{D}_{2} \mathrm{~N}_{2}$ & 97.3 & 41.9 & 139.2 & 26.2 & 13.7 & 39.9 & 24.2 & 110.7 & 134.9 & 313.9 \\
\hline $\mathrm{D}_{2} \mathrm{~N}_{3}$ & 107.2 & 46.8 & 154.0 & 31.3 & 14.9 & 46.2 & 26.8 & 121.3 & 148.1 & 348.3 \\
\hline $\mathrm{D}_{2} \mathrm{~N}_{4}$ & 118.8 & 56.9 & 175.7 & 34.2 & 16.8 & 51.0 & 29.3 & 137.4 & 166.7 & 393.3 \\
\hline $\mathrm{D}_{3} \mathrm{~N}_{1}$ & 100.5 & 42.9 & 143.4 & 26.7 & 13.9 & 40.6 & 24.7 & 113.5 & 138.2 & 322.2 \\
\hline $\mathrm{D}_{3} \mathrm{~N}_{2}$ & 106.1 & 47.6 & 153.7 & 29.1 & 14.9 & 44.0 & 28.9 & 124.6 & 153.5 & 351.2 \\
\hline $\mathrm{D}_{3} \mathrm{~N}_{3}$ & 116.8 & 51.1 & 167.9 & 34.1 & 16.5 & 50.6 & 30.2 & 133.2 & 163.4 & 381.9 \\
\hline $\mathrm{D}_{3} \mathrm{~N}_{4}$ & 126.7 & 60.1 & 186.8 & 36.0 & 17.9 & 53.9 & 34.3 & 144.7 & 179.0 & 419.7 \\
\hline
\end{tabular}


Table.4 Nutrient balances (kg ha-1) of no-till maize under rice fallows as influenced by planting density and $\mathrm{N}$ application

\begin{tabular}{|c|c|c|c|c|c|c|c|c|c|c|c|c|}
\hline \multirow{2}{*}{ Treatments } & \multicolumn{3}{|c|}{ Nutrients added } & \multicolumn{3}{|c|}{ Nutrients Removed (B) } & \multicolumn{3}{|c|}{ Soil available nutrients $(\mathrm{C})$} & \multicolumn{3}{|c|}{ Actual gain/loss $\left(\mathbf{C}-\mathbf{A}^{*}\right)$} \\
\hline & $\mathbf{N}$ & $\mathbf{P}_{2} \mathbf{O}_{5}$ & $\mathbf{K}_{2} \mathbf{O}$ & $\mathbf{N}$ & $\mathbf{P}_{2} \mathbf{O}_{5}$ & $\mathbf{K}_{2} \mathbf{O}$ & $\mathbf{N}$ & $\mathbf{P}_{2} \mathbf{O}_{5}$ & $\mathbf{K}_{2} \mathbf{O}$ & $\mathbf{N}$ & $\mathbf{P}_{2} \mathbf{O}_{5}$ & $\mathbf{K}_{2} \mathbf{O}$ \\
\hline $\mathrm{D}_{1} \mathrm{~N}_{1}$ & 120 & 60 & 40 & 100.6 & 28.1 & 99.4 & 202.0 & 39.9 & 733.0 & 10.5 & 3.0 & -6.5 \\
\hline $\mathrm{D}_{1} \mathrm{~N}_{2}$ & 180 & 60 & 40 & 115.3 & 32.1 & 117.1 & 209.5 & 43.8 & 746.5 & 18.0 & 6.5 & 7.0 \\
\hline $\mathrm{D}_{1} \mathrm{~N}_{3}$ & 240 & 60 & 40 & 128.9 & 37.1 & 132.1 & 214.5 & 45.4 & 765.5 & 23.0 & 8.5 & 26.0 \\
\hline $\mathrm{D}_{1} \mathrm{~N}_{4}$ & 300 & 60 & 40 & 147.5 & 41.3 & 147.1 & 224.0 & 48.9 & 778.5 & 32.5 & 12.0 & 39.0 \\
\hline $\mathrm{D}_{2} \mathrm{~N}_{1}$ & 120 & 60 & 40 & 123.6 & 34.0 & 119.6 & 192.5 & 36.0 & 703.0 & 1.0 & -1.0 & -36.5 \\
\hline $\mathrm{D}_{2} \mathrm{~N}_{2}$ & 180 & 60 & 40 & 139.2 & 39.9 & 134.9 & 204.0 & 37.4 & 734.5 & 12.5 & 0.5 & -5.0 \\
\hline $\mathrm{D}_{2} \mathrm{~N}_{3}$ & 240 & 60 & 40 & 154.0 & 46.2 & 148.1 & 210.5 & 39.7 & 745.5 & 19.0 & 2.5 & 6.0 \\
\hline $\mathrm{D}_{2} \mathrm{~N}_{4}$ & 300 & 60 & 40 & 175.7 & 51.0 & 166.7 & 217.5 & 43.9 & 752.5 & 26.0 & 7.0 & 13.0 \\
\hline $\mathrm{D}_{3} \mathrm{~N}_{1}$ & 120 & 60 & 40 & 143.4 & 40.6 & 138.2 & 184.5 & 34.5 & 694.0 & -7.0 & -2.5 & -45.5 \\
\hline $\mathrm{D}_{3} \mathrm{~N}_{2}$ & 180 & 60 & 40 & 153.7 & 44.0 & 153.5 & 194.5 & 35.5 & 715.0 & 3.0 & -1.5 & -24.5 \\
\hline $\mathrm{D}_{3} \mathrm{~N}_{3}$ & 240 & 60 & 40 & 167.9 & 50.6 & 163.4 & 200.5 & 36.5 & 735.5 & 9.0 & -0.5 & 4.0 \\
\hline $\mathrm{D}_{3} \mathrm{~N}_{4}$ & 300 & 60 & 40 & 186.8 & 53.9 & 179.0 & 209.5 & 39.3 & 744.0 & 18.0 & 2.5 & 4.5 \\
\hline
\end{tabular}

*Initial soil status 191.5- 37.0- 739.5 kg N-P $\mathrm{O}_{5}-\mathrm{K}_{2} \mathrm{O}_{\text {ha }}{ }^{-1}(\mathrm{~A})$ 
Perusal of data on economics indicated that irrespective of planting densities, the enhancement of nitrogen application increased the gross, net returns and BCR which was in consonance with the results of Ameta and Dhakar (2000) and Bisht et al. (2013). The highest gross, net returns and BCR were obtained at $D_{3}$ followed by $D_{2}$ and $\mathrm{D}_{1}$. The highest net income (₹ 43369/and (₹ 61043/-) and BCR (1.75 and 2.46 in first and second year of study) was obtained at highest level of planting density (100000 plants ha ${ }^{-1}$ ) and with application of $300 \mathrm{~kg} \mathrm{~N}$ $\mathrm{ha}^{-1}$ (₹ 56374/- and ₹ 64358/-) followed by $240 \mathrm{~kg} \mathrm{~N} \mathrm{ha}{ }^{-1}$ due to higher kernel yields. The lowest net returns and BCR obtained at lower planting density and lower nitrogen levels was due to more cost incurred in cultivation of rice fallow maize. The results of higher yields and net returns were also observed at higher dose of $180 \mathrm{~kg} \mathrm{~N}^{-1}$ compared to $120 \mathrm{~kg} \mathrm{~N}^{-1}$ in rabi maize (Tank et al., 2006). These findings are in confirmation with the results of Raskar et al. (2013).

\section{Soil Fertility}

The data on post-harvest status of available $\mathrm{N}, \mathrm{P}$ and $\mathrm{K}$ in soil are presented in the table 4. Available nutrient status in soil after harvest was affected significantly due to various N levels. Significant variation in available $\mathrm{N}, \mathrm{P}$ and $\mathrm{K}$ in soil was observed with each successive increase in $\mathrm{N}$ levels. Irrespective of the rate of $\mathrm{N}$ application, the status of available N P K after harvest of maize was reduced with increase in planting density from 67000 plants ha ${ }^{-1}$ to 100000 plants ha ${ }^{-1}$.

The available N P K status was found superior with lower planting density of 67000 plants $\mathrm{ha}^{-1}$ than the rest of higher planting densities (80000 plants $\mathrm{ha}^{-1}$ and 100000 plants ha ${ }^{-1}$ ). The higher quantities of available N P K found at lower planting density (67000 plants ha $^{-1}$ ) might be due to lower uptake of nutrients by the crop from the soil.

The status of N P K in soil after harvest of maize increased with increase in level of $\mathrm{N}$ application from 120 to $300 \mathrm{~kg} \mathrm{~N} \mathrm{ha}^{-1}$ during both the years of the experimentation. Increase in the level of $\mathrm{N}$, assured the availability of $\mathrm{N} \mathrm{P} \mathrm{K} \mathrm{nutrients} \mathrm{to} \mathrm{the} \mathrm{crop}$ plants in adequate amount and remained in soil in substantial quantity after fulfilling the crop requirement that ultimately improved the soil fertility. It was further confirmed by the findings of Halvorson and Jantalia (2011) and Paramasivan et al. (2011).

In conclusion, from the trial conducted for two consecutive years, it was clearly evident that adoption of higher level of planting density (80000 plants ha $^{-1}$ ) with application of $240 \mathrm{~kg} \mathrm{~N} \mathrm{ha}{ }^{-1}$ under zero tillage conditions was found to be optimum for getting higher yields. Narrow rows maize with optimal level of $\mathrm{N}$ is a simple management practice that could contribute to enhancing the sustainable productivity under rice fallow situations.

\section{References}

Ameta, G. S. and Dhakar, L. L. 2000. Response of winter maize (Zea mays L.) to nitrogen levels in relation to varying population density and row spacings. International Journal of Tropical Agriculture. 18(4): 395398.

Ananthi, T., Amanullah, M.M. and Subramanian, K.S. 2010. Influence of mycorrhiza and synthetic fertilizers on soil nutrient status and uptake in hybrid maize. Madras Agricultural Journal. 97(10-12):374-378.

Anonymous, 2015. Directorate Economics and Statistics. http://www.ficci.com/ spdocument/20386/India-Maize2014_v2.pdf.

Barbieri, P.A., Echeverria, H.E. and Sainz Rozas, H.R. 2008. Presidedress soil nitrogen test for 
no-tillage maize at different row spacing. Agronomy Journal. 100: 1101-1105.

Bharathi, S. 2010. Productivity and nitrogen requirement of maize (Zea mays L.) in rabi as influenced by kharif cropping practices. Ph. D (Agri.) Thesis, Acharya N.G.Ranga Agricultural University, Hyderabad.

Bisht, A.S., Amit, B. and Singh, V. 2013. Influence of plant density and integrated nutrient management on $\mathrm{N}, \mathrm{P}$ and $\mathrm{K}$ contents and uptake of quality protein maize. Madras Agricultural Journal. 100 (1-3): 110-112.

Emam, Y. 2001. Productivity of grain yield components to plant population density in non-prolific maize (Zea mays L.) hybrids. Indian Journal of Agricultural Sciences. 71 (6):367-70.

Halvorson, A.D. and Jantalia, C.P. 2011. Nitrogen fertilization effects on irrigated no-till corn production and soil carbon and nitrogen. Agronomy Journal.103 (4): 1423-1431.

Jantalia, C.P. and Halvorson, A.D. 2011. Nitrogen fertilizer effects on irrigated conventional tillage corn yields and soil carbon and nitrogen pools. Agronomy Journal. 103:871878.

Lakshmi, N. V. 2010. Nitrogen requirement of rice fallow maize (Zea mays L.) as influenced by nitrogen management in rice. $\mathrm{Ph}$. D Thesis, Acharya N G Ranga Agricultural University, Hyderabad, India.

Paramasivan, M., Kumarsen, K. R. and Malarvizhi, 2011. Effect of balanced nutrition on yield, nutrient uptake and soil fertility of maize (Zea mays L.) vertisol of TamilNadu. Indian Journal of Agronomy. 56 (2): 133-137.

Raskar, S.S., Sonani, V.V. and Patil, P.A. (2013). Study of economics of maize as influenced by different levels of nitrogen, phosphorus and zinc. International Journal of Scientific and Research Publications. 3(10):1-3.

Reddy M. M., Padmaja B. and Reddy D. V. V. 2012. Response of maize (Zea mays L.) to irrigation scheduling and nitrogen doses under no-till condition in rice fallows. J Res, ANGRAU. 40(1): 6-12.

Savitha, M., Bedi, S. and Vashist, K. K. 2011. Performance of winter maize (Zea mays L.) hybrid to planting methods and nitrogen levels. Indian Journal of Agricultural Sciences. 81 (1):50-54.

Sutaliya, R. and Singh, R. N. 2005. Effect of planting time, fertility level and phosphorussolubilizing bacteria on growth, yield and yield attributes of winter maize (Zea mays L.) under rice (Oryza sativa) - maize cropping system. Indian Journal of Agronomy. 50(3): 173-175.

Tank, D. A., Patel, S. K. and Usadadia, V. P. 2006. Nitrogen management in rabi maize (Zea mays L.). Crop Research 31(2): 323-324.

Van Roekel R.J. and Coulter J.A. 2011. Agronomic response of corn to planting date and plant density. Agronomy Journal. 103:1414-1422

Venkata Rao, P., Subbaiah, G., Veeraraghavaiah, R., Ashoka Rani, Y and Srinivasa Rao, V. 2014. Effect of plant density and nitrogen levels on productivity and economics of rice fallow maize under zero-tillage conditions. The Andhra Agricultural Journal. 61(1):612.

Vishalu, L., Nagaraju Nanjappa, H. V., Kalyanamurthy, K. N., Devakumar, and Kalaraju, 2009. Performance of hybrid maize to plant density and fertilizer levels under rain fed conditions. Crop Research. 37(1, $2 \& 3)$ : 49-51.

\section{How to cite this article:}

Venkata Rao, P., G. Subbaiah and R.Veeraraghavaiah. 2016. Productivity and Nutrient Uptake of Rice Fallow Maize (Zea mays L.) as Influenced by Plant Density and Fertilizer N Under NoTill Conditions. Int.J.Curr.Microbiol.App.Sci. 5(6): 827-836.

doi: http://dx.doi.org/10.20546/ijcmas.2016.506.091 